\title{
The Cistercian model? The application of the grange system by the various religious orders in the Frisian coastal area, 1150-1400
}

\author{
[Preprint]
}

\section{J.A. Mol}

In the high and late Middle Ages, the Frisian coastal region made up a real monastic landscape. Around 1300, the territory congruent to the present-day Dutch provinces of Friesland and Groningen, which composed the greater part of Medieval Frisia, ${ }^{1}$ counted no less than 50 religious houses. ${ }^{2}$ The friaries excluded, these houses belonged to the orders of the Cistercians, the Premonstratensians, and the Augustine Canons, along with some filiations of reformed Benedictines, the Hospitallers, and the Teutonic Order. Though the members of these orders sought distance from the everyday world, they left a mark on both society and the landscape. The building complexes of their communities, often situated in moated sites of more than five acres in size, were visible from afar in the flat and treeless land along the North Sea.

It is a matter of discussion whether the more than 100 parish churches in Frisia that were then administered by monks and regular canons should be added to this religious landscape, as most of them had had not been founded by monasteries. The monastic granges or outlaying estates, staffed by lay brothers - on the other hand - certainly made part of it. These granges were significant in number and extent. In the middle of the fourteenth century, for example, the 38 main monasteries of Frisia between Vlie and Ems (i.e. the provinces of Friesland and Groningen) together possessed no less than 173 granges. ${ }^{3}$ Nearly every abbey with its dependent nunnery formed the center of a web of granges, each of which may have put a stamp on the surrounding landscape.

In general, the grange system is attributed to the Cistercians, or at least they are thought to have developed it to its full extension, with the Premonstratensians following their track. ${ }^{4}$ In the Frisian coastal region all orders are known to have applied the system. This does not directly contradict the idea that the Cistercians provided the model for the grange, but it does raise the question of whether the latter really introduced the institution to the area, because they were not the first monks to settle here. To answer the question of the grange system's origin and spread in Frisia, in this paper, I analyze several of the ca. 173 granges that could be identified as having belonged to Frisian and Groningen monasteries, in terms of their extent, their function, their structure, their place in space and the background of the house to which each was attached.

\section{Frisia and the shaping of its monastic landscape}

\footnotetext{
${ }^{1}$ The German Landschaft Ostfriesland, which also made up part of medieval Frisia, had the same monastic outlook. It was occupied by the same orders and boasted many religious houses that were affiliated with the abbeys, priories and commanderies west of the Ems. For an overview, see M. Smid, Ostfriesische Kirchengeschichte (Pewsum, 1974) pp. 87-114; and G. Streich, Gerhard, Klöster, Stifter und Kommenden in Niedersachsen vor der Reformation (Hildesheim, 1986). Since the documentation on the granges of these East Frisian monasteries is very scarce by want of sources, this region had to be left aside.

${ }^{2}$ An introduction is presented in J.A. Mol, 'Bemiddelaars voor het hiernamaals. Kloosterlingen in middeleeuws Frisia’, in: E. Knol, J.M.M. Hermans en M. Driebergen red., Hel en hemel. De Middeleeuwen in het Noorden (Groningen, 2001) pp. 152-164. Compare: J. Loer and H.J. Kooi, Kloosterland, Land der Klöster (Assen, 2008).

${ }^{3}$ This figure is the result of recent research. Details on the granges west of the Lauwers can be consulted at the www.hisgis.nl site, in the 'uithoven' layer concerning the province of Friesland. The data on the Groningen granges will be presented at the same site s.v. Groningen in the course of 2014.

${ }^{4}$ The statement of Colin Plat that ' ...the Cistercians, seeking economic as well as spiritual advantage, pioneered the institution both in England and on the Continent', has never been questioned: The Monastic Grange in Medieval England (London 1969), p. 12. Compare B. van Bavel, Manors and Markets. Economy and Society in the Low Countries, 500-1600 (Oxford, 2010), pp. 91, 223-224.
} 
Before getting to the theme of the origin of the grange system in Frisia, some information is needed on the peculiarities of Frisia and its monasteries. ${ }^{5}$ Though the region was already Christianized in the eighth and ninth centuries, it did not establish its own monasteries until $1100 .^{6}$ Apparently, the inhabitants continued for quite some time to entrust their salvation prayers to the Benedictine monks at the abbeys of Echternach, Fulda, Werden, Prüm etc. which had been founded by their non-Frisian missionaries deep in the Carolingian heartland. It was only after Christianity had taken deeper root in the region that devout Frisians began to think about founding and funding prayer houses of their own in the vicinity. This situation provided nearly all extant orders of the early twelfth century the same starting position for recruiting members Kings, bishops, or other great lords, did not hinder the orders in their Frisian expansion so they could - in a certain sense - freely compete with one another. This must be connected to the fact that Friesland was an elongated collection of lands whose fragmentation prevented the rise of feudalism in this era. The comital rights on the various lands had come into the hands of a series of non-Frisian rulers, who, because of the distances involved in rule, were impeded from developing their respective jurisdictions into a real territorial dominion. This lack of central control opened up the way for the native aristocracy to organise a kind of semi-communal government in each region. Monasteries, therefore, had to rely mainly on the local elite for sponsorship and recruitment, although they also received sporadic support from distant bishops and counts as well.

As for the sequence of the monastic foundations, it has to be emphasized that the Cistercians and Premonstratensians were not the first religious orders to settle in Frisia. That honour was reserved for the Benedictines, who in 1132 - with the help of the bishop of Utrecht, took over a chapter of secular canons in the port of Staveren, which was the central place of the terra Sudergo. ${ }^{7}$ This occurred at a time when the bishop could still exercise comital rights in Sudergo. As he was a supporter of the Gregorian reform movement, he promoted the transfer to Staveren of reformed Benedictines from the newly founded StLaurens abbey of Oostbroek, near Utrecht, which in its turn had been peopled by monks from the late eleventh century reform monastery of Affligem in Brabant. ${ }^{8}$

The second new monastic settlement in Friesland was sponsored by the bishop of Utrecht as well. It was called Ludingakerke, after the place where it was founded, not far from the later port of Harlingen. It can be seen as the first religious community in the terra of Westergo. ${ }^{9}$ The initiative for its founding seems to have been taken by a local noble family who was related to the Utrecht bishop Hartbert of Bierum. Through Hartbert the new community had been connected to the well-known abbey of the Augustine canons of Kloosterrade (better known by its later name Rolduc), which was located between Aix-laChapelle and Heerlen, and which had its roots in the vita apostolica movement. Founded around 1104, this Augustine monastery in Limburg succeeded in forming a small congregation of dependent abbeys and priories of its own.

\footnotetext{
${ }^{5}$ See the headwords 'Friesen, Friesland', in: Lexikon des Mittelalters IV (Stuttgart/Weimar, 1999) kol. 970-976; O. Vries, 'Geschichte der Friesen im Mittelalter: West- und Ostfriesland', in: H.H. Munske ed., Handbuch des Friesischen / Handbook of Frisian Studies (Tübingen, 2001) pp. 538-549.

${ }^{6}$ Apart then from a few minsters or chapters of secular canons which served as mission centres. J.A. Mol, 'Friesische Freiheit in Kirchspiel und Kloster', in: Hajo van Lengen ed., Die Friesische Freiheit des Mittelalters - Leben und Legende (Aurich, 2003) pp. 194-245.

${ }^{7}$ J.A. Mol and K. van Vliet, 'De oudste oorkonden van het Sint-Odulfusklooster van Staveren', Jaarboek voor Middeleeuwse Geschiedenis 1 (1998) pp. 73-74.

${ }^{8}$ C.J.C. Broer, Monniken in het moeras. De vroegste geschiedenis van de abdij van Sint-Laurens in het Oostbroek bij Utrecht (Utrecht, 2011) pp. 73-84.

${ }^{9}$ J.A. Mol and P.N. Noomen, 'De stichting van de Augustijner koorherenabdij Ludingakerke en haar relatie met Rolduc', in: S. Zijlstra, G.N.M. Vis en D.J.M. Zeinstra ed., Vroomheid tussen Vlie en Lauwers. Aspecten van de Friese kerkgeschiedenis (Delft, 1996) pp. 11-46.
} 
It does not seem a coincidence therefore, that the next monastic settlements in Friesland were founded in yet another terra, Oostergo, and were populated by members of yet two other orders: the Cistercians and the Premonstratensians. The first of them, called Clarus Campus or Klaarkamp in imitation of Saint Bernard's famous abbey of Clairvaux, arose near the village of Rinsumageest, not far from Dokkum. ${ }^{10}$ Klaarkamp must have existed by 1163 , although it was admitted as an abbey into the order only in 1165 . The settlement was known to be one of the many daughters of Clairvaux. In its early decades however, it received guidance from the Saxonian abbey of Rittagshausen near Braunschweig, which belonged to the filiation of Morimond.

The second monastery of Oostergo was established at nearly the same time as Klaarkamp. This was Ortus Sancte Marie (Dutch: Mariëngaarde) near Hallum, north of Leeuwarden. ${ }^{11}$ Its founder, Frederic, who was rector of the local parish church, is said to have known the Cistercian monks of Klaarkamp and to have assisted them initially. According to the Vita Fretherici however, Frederic withdrew his support for Klaarkamp when he learned that these new Frisian white monks only accepted rich men and women as novices. He then decided to found an independent community on his own land in 1163 and planned to incorporate it into the Premonstratensian order. That is to say, Frederic endeavoured to place his followers under the guidance of the austere Premonstratensian abbey of Steinfurt in the Eifel. The incorporation process for this new monastery took about a decade and was only achieved after a new house had been built for the sisters which had probably joined in at the start. The new nunnery was located about 10 kilometers east of Hallum in a place that received the name of Bethlehem. This development of a convent starting as a group of men and women living and praying at the same location, ending up in two separate but mutually dependent monasteries, can be considered typical for the Frisian monastic landscape. ${ }^{12}$ Nearly all explicitly religious communities in Friesland, even those of Staveren and Ludingakerke, began by admitting Christians of both sexes. They had to be divided into separate communities once their leaders decided to join an official order. In most cases, the solution for dividing the sexes was to leave the men at the original site and to create a dependent nunnery - led by a prior and a prioress - for the women at another location. These nunneries then stayed dependent of the male community in every aspect: economically, legally and spiritually. Consequently, there never have been Frisian abbesses nor autonomous abbeys for women in Frisia.

The number of religious communities in Frisia increased substantially after these four main abbeys, each attached to another order, had been founded in three different regions (terrae) in Frisia west of the river Lauwers. Each of these first houses became the mother of a family of daughter communities, male and female. The first of these daughter communities were established in the terrae east of the Lauwers: in Hunzingo and Fivelgo, and, even further to the east, in the East Frisian Emsingo. It was as if the new orders feared competition with each other and tried to avoid becoming close neighbours. However, when sponsors were abundant, daughter houses of various orders were founded in all regions. The oldest of these are always found in or near the centre of each terra; the younger and poorer communities were found at the geographical margins, where the material perspectives were less favourable.

In this competition, the military orders also made their appearance. ${ }^{13}$ This happened in the first decades of the thirteenth century, more or less as the result of the massive Frisian

\footnotetext{
${ }^{10}$ J.A. Mol, 'De stichting fan it Cistersiënzer kleaster Klaarkamp by Rinsumageast', It Beaken 58 (1996) pp. 113; idem, 'Klaarkamp bij Rinsumageest: de ruimtelijke ontwikkeling van terp en klooster', Fryslân. Nieuwsblad voor geschiedenis en cultuur 12 (2006), nr. 2, pp. 5-12.

${ }^{11}$ J.A. Mol, 'Mariëngaarde, het Friese kloosterwezen en de Friese maatschappij', in: H.Th.M. Lambooij and J.A. Mol ed., Vitae Abbatum Orti Sancte Marie. Vijf abtenlevens van het klooster Mariëngaarde in Friesland (Hilversum/Leeuwarden 2001) pp. 59-109, 59-66, 176-179.

12 J.A. Mol, 'The Hospitaller Sisters in Frisia', in: Anthony Luttrell and Helen J. Nicholson ed., Hospitaller Women in the Middle Ages (Aldershot, 2006) pp. 179-208; 184-186.

${ }^{13}$ J.A. Mol, 'The Beginnings of the Military Orders in Frisia', in: H. Nicholson ed., The Military Orders. Vol. 2
} 
participation in the fifth crusade, which led the Christian armies to Damietta in the Egyptian Nile delta. As in that period the best places had already been occupied by the abovementioned orders, most Frisian houses of the Hospitallers and the Teutonic Knights could only be established in settlements upstream, with small perspectives on acquiring substantial donations. Only their first commanderies, which were built in fertile border zones of the old inhabited terrae of Westergo, Oostergo and Hunzingo - being the settlements in Sneek, Nes, Warffum and Wijtwerd - succeeded in attaining a certain wealth.

\section{The documentation on the Frisian granges}

At first sight, retrieving information on the granges of all these Frisian monasteries seems difficult due to the less than abundant sources on the matter. Only few monastic records have survived the Reformation and the acts of war in the first phase of the Dutch Revolt. Some chronicles, some fragmented charter collections, and some rental and lease books from the fifteenth and sixteenth centuries have been preserved. The latter, however, do not provide much insight into the active landownership of the monks in early centuries. Nearly all domestic and manorial accounts from the thirteenth and fourteenth centuries have been lost. Compared to the rich monastic sources that are extant for particular English and Flemish regions, the harvest for the Frisian coastal area is thus markedly poor.

For both the Frisian and Groningen monasteries, however, we fortunately have fairly complete suppression inventories at our disposal. On the basis of fiscal and other serial administrative sources from the eighteenth and seventeenth centuries these inventories can be linked to the Napoleonic cadastre of the early nineteenth century. This, in turn, makes it possible to reconstruct in great detail the estates of the monasteries at the time of their dissolution (1580/1594). ${ }^{14}$ Of course, reconstruction means that loss of data has to be taken into account, but $80 \%$ of the property could be mapped. Because the data of the early cadastre of the provinces of Friesland and Groningen has been stored in a parcel structured historical GIS, the digital maps of the sixteenth century monastic property can be combined and compared with all kinds of data sets and GIS mapped interpretations of Frisian landscape history. ${ }^{15}$ Examples of these are soil maps, altitude maps, aerial photographs, and collections of localized field and farm names.

It is these place names which have proven to be reliable guides following the traces of the estates back to the hey-day of monastic economic activity in the Frisian coastal area. The essential fact here is that in the province of Friesland a large part (namely 36) of the granges were originally called monnikhuizen (monk houses) or monnikhoven (monk manors), and that these original names have become 'fossilized' in the names of the later farms. In the province of Groningen, the majority were known as voorwerken. Another common designation, besides the Latin grangia, curia and curtis, is uithof, which literally means 'outlying manor'. Unlike the designations voorwerk and uithof, which do not refer to owners or users, the appellative 'monk house' or 'monk land' gives a clue as to who used the property. I would like to underline the importance of the day to day usage here, because in onomastics it is a rule that

\footnotetext{
Welfare and Warfare (Aldershot, 1998) pp. 307-317.

${ }^{14}$ P.N. Noomen and J.A. Mol, 'Die Bedeutung des friesischen Katasters von 1511/1640 für die historische Siedlungsforschung’, in: Siedlungsforschung: Archäologie-Geschichte-Geographie 14 (Bonn 1996 [1998]) pp. 217-235; for the province of Friesland, the retrospection method is exemplified in annex 3 of J.A. Mol, De Friese huizen van de Duitse Orde (Leeuwarden, 1991), pp. 325-339; for the province of Groningen, see B.W. Siemens, Historische atlas van Groningen, vol. 1 (Groningen 1962), pp. 86 ff.

${ }^{15}$ www.hisgis.nl. For a short explanation on the use of GIS in this field see J.A. Mol, 'Monasteries and water management in the Frisian coastal plain. The reconstruction of landed property as a trigger for new research on the chronology of embankment and drainage', in: E. Thoen e.a. (red.), Landscapes or seascapes? The history of the coastal environment in the North Sea area reconsidered. Corn Publication Series 13 (Turnhout 2013) 267286.
} 
in appellative constructions of field names, indications of persons always refer to men of women who were present at the very place. ${ }^{16}$ Besides their core property, distant large owners were rarely found mentioned in the names of their farms. In the case of monk house, this leads us to the question of the status of the 'monks' whose names were given to these places.

Some authors argue that outlying monastic estates were in the Middle Ages hardly perceived as being religious property, since the clergy, apart from a few lay brothers, were seldom present on their farms. ${ }^{17}$ However, I believe this observation might be misleading and that monastic estates were considered religious proper. Lay brothers were indeed the main representatives of the monasteries in the countryside. It is clear that in the Frisian case - and this holds for the whole coastal area, from Alkmaar in the north of Holland up to Bremen in Germany - 'monk' in place names always refer to lay brothers: to the monachi conversi, as they were called in Latin. ${ }^{18}$ The main argument to support this statement is that granges and other estates of orders like the Augustine and Premonstratensian canons, whose praying members were not known as monachi and who did not address themselves as such, nevertheless were designated as monk houses and monk lands. Most convincing perhaps in this regard is the fact that many granges of nunneries and of sisters houses of the military orders always received monk names like 'Wijtwerder Monken', Oosterwierumer Monken’ and 'Tjücher Monken', and this pattern even extended to the central building complexes with adjoining lands. ${ }^{19}$ The nunnery of the Premonstratensian abbey of Lidlum, south of the city of Franeker, officially named Mons Sancti Michaëlis, was in the vernacular better known as Monnikebajum: that part of the parish of Bajum which was occupated by monks. ${ }^{20}$ This strongly suggests that the people in the vicinity were a lot more familiar with the Premonstratensian lay brothers' presence and activity in the precincts, than they were with the enclosed nuns singing in the church. It also means that the common folk saw these monachi conversi as the main representatives of the monasteries - which was not entirely wrong from both our modern and the medieval perspective, since especially in the twelfth and thirteenth centuries a large number of lay brothers were indeed an integral part of the religious communities. The number of lay brothers - at least in the reform orders of the eleventh and twelfth centuries - exceeded by far that of their fellow brethren who did praying work. ${ }^{21}$ To consider conversi only as associated work forces would not do them justice.

According to the data, the names of monnikhuizen appear to always refer to monastic estates where lay brothers were active in the period before direct exploitation ceased. Even if we dispose of late attestations of these names, from the sixteenth and seventeenth centuries for example, this rule of thumb appears to be valid. That is to say, in the same way as names containing the affix 'galg' (= gallows), like galgeland, almost always indicate places where once a real exposition or executing device stood, ${ }^{22}$ the term 'monnik' indicates the actual presence of monks. The vernacular designations voorwerk and uithof are less absolute in this interpretation, although I never found any that have been used to designate a secular manor in

\footnotetext{
${ }^{16}$ E. Schubert, 'Grundherrschaft im Lichte der Namenforschung', in: H. Patze ed., Die Grundherrschaft im späten Mittelalter II, Vorträge und Forschungen 27 (Sigmaringen, 1983) pp. 75-96; 90-93.

${ }^{17}$ S. Moorhouse, 'Monastic Estates: their Composition and Development', in: R. Gilchrist and H. Mytum ed., The Archaeology of Rural Monasteries (Oxford, 1989), pp. 29-81; 58.

${ }^{18}$ A.W. Wybrands, De abdij Bloemhof te Wittewierum in de $13^{e}$ eeuw (Amsterdam, 1883). p. 5.

19 J.A. Mol, 'The Hospitaller Sisters in Frisia', in: Anthony Luttrell en Helen J. Nicholson ed., Hospitaller Women in the Middle Ages (Aldershot, 2006) pp. 179-208; 198-199.

${ }^{20}$ Mol, 'Mariëngaarde, het Friese kloosterwezen en de Friese maatschappij', p. 73.

${ }^{21}$ M. Toepfer, Die Konversen der Zisterzienser. Untersuchungen über ihren Beitrag zur mittelalterlichen Blütes des Ordens (Berlin, 1983), pp. 52-58; B. Krings, B., 'Laien im Kloster und seinem Umfeld im Mittelalter', in: Hospitalitas en de aanwezigheid van leken in de middeleeuwse premonstratenzer kloosters, Werkgroep Norbertijner Geschiedenis in de Nederlanden. Bijdragen van de contactdag 12 (Averbode, 2002) pp. 31-46; 3638.

${ }^{22}$ J.A. Mol, 'Gallows in late medieval Frisia'; a Rich Internet Publication: www.cs.uu.nl/research/projects/icult/xposre/demo/gallows/.
} 
the provinces of Friesland and Groningen. We can therefore ascertain, that if we come across a voorwerk or uithof toponym on former monastic lands, there must have been a grange at the spot.

So, besides the scarce contemporary evidence from charters and chronicles on grangiae, curtes and conversi or lay brothers, and some data on well-documented granges, our material only consists of names. The larger part of these names, however, can be interpreted against the visual background of the property to which they are attached; visual, because the data of the dissolution inventories allows us to map four-fifths of the monastic lands as they were at the end of the sixteenth century. It is even possible in many cases to retrace the size and shape of the lands that had belonged to the former granges in their functional phase. When the grange system gradually broke down in Frisia in the fourteenth and early fifteenth century, most granges were divided in three to five separate farms that could be leased out to wealthy tenants. ${ }^{23}$ Both in the inventories and their cadastral mapping a lot of these units can be recognized as the compositional elements of the former granges. Especially for those granges that had been isolated geographical structures physically apart from the core of the monastic demesne, it is comparatively easy to bring the constituent elements together.

\section{Some figures on the identified granges and their functions}

Considering all this, it goes without saying that the data does not allow us to stretch our conclusions very far. It is, however, not impossible to give some more detailed figures (see annex 1). Arranging them according to orders, we find that most granges (48) were owned and used by the Premonstratensians, that the Cistercians had at least 44 and the Benedictines 38, while - as far as we know - the military orders owned 24 of these units. More interesting perhaps is the ratio of the number of granges per monastery. 173 granges on 38 monasteries (the nunneries left aside) make nearly five granges per monastery. ${ }^{24}$ Looking at the average per order, it will come as no surprise that the Cistercians achieved the best score, since they boasted 7,3 granges per abbey with their six male monasteries. The Benedictines, Augustinian canons and the Premonstratensians follow with about 4 to 4,5 granges per monastery. As might be expected, the score of the Hospitallers and the Teutonic order is lower, with 3 granges per preceptory.

Within the separate orders, a ranking by age of the monasteries can be made as well. For the oldest Benedictine abbeys in Frisia, those of Staveren/Hemelum (1132) and Feldwerd (ca. 1180) 16 and 7 granges respectively can be listed. The abovementioned Augustine abbey of Ludingakerke (1158) founded at least 9 monk houses. The Premonstratensian abbeys of Mariëngaarde (1163), Lidlum (1182) and Bloemhof or Wittewierum (1214) each scored fairly high with 9, 12 and 10 granges. In fact, they owned as many granges as the richest Cistercian abbeys in the province of Friesland: Klaarkamp (1163) and Aduard (1192) who had 10 and 12 respectively. These figures allow us to draw two conclusions, the first being that the oldest abbeys succeeded in acquiring and building the most granges. This is only logical, because they started as novel institutions in the region and therefore were able to attract the richest sponsors and largest numbers of enthusiastic lay brothers. The second conclusion is that the large Premonstratensian houses had as many of these outlying estates as the Cistercian ones. In their case, the low number of granges per monastery was the result of the fact that unlike the Cistercians the Premonstratensians had admitted into their order several small houses with modest means (e.g. priories and Propsteien), which pushed down the average.

\footnotetext{
${ }^{23}$ This occurred in the course of the fourteenth century: Mol, Friese huizen van de Duitse Orde, p. 76; idem, 'Het uithofsysteem van het klooster Bergum in Friesland', Historisch Geografisch Tijdschrift 22 (2004) pp. 73-85; 8283.

${ }^{24}$ Note that the dependent nunneries are not counted as monasteries or granges in these calculations.
} 
Most granges of these Frisian monasteries could be localized in the provinces of Friesland and Groningen within a certain range of the house to which they belonged. Some however, are found outside the borders of the terrae in which their abbeys were founded. In particular, the oldest houses of the four main orders in Friesland west of the Lauwers acquired several outlying properties, partly because they had been supported in this by the count of Holland and the bishop of Utrecht. For instance, around 1200, the Benedictine abbey of Staveren owned no less than 6 granges in the Holland and the Zuiderzee area. Ludingakerke had 2 granges on the isle of Texel and 1 near the parish church of Monnikendam, whilst Mariëngaarde exploited 2 curiae on the isle of Marken. These were territories and places that in the thirteenth century all came under the control of of Holland.

It will be clear that not all these units had the same function. Most of them were agrarian production centers. The basic idea behind the system was that it was operated by the religious orders themselves to offer their communities all necessities of life without compromising their seclusion from the world. In theory therefore, the community strove to be self sufficient. However, as many authors have stated, in practice the grange system proved to be an economical success because it led to specialization and surplus production. ${ }^{25}$ Initially, it seems that the monks brought only those products to the market which they could use or consume in the monastery itself. After some time however, a considerable part of the grange production was sold in the cities to make pecuniary profits needed to buy necessities for the monastery, even including foodstuffs. This development led to the acquisition of monastic town houses that could function as staple centers to hold wares intended for market purposes. ${ }^{26}$ These monk houses in the cities could - at the same time - be used as places of refuge in times of unrest, or as residences for abbots and other high ranked officials.

The figures indicate that the Frisian monasteries did not own many of these urban monk houses. We count only 12 of a total of 173 granges, most of which were located in the largest city of the North, Groningen. Interesting, however, in this respect is that several reports suggest that Frisian monasteries in the thirteenth and early fourteenth century were active participants in town markets, not in their own regions but in the Flemish and NorthWest German Hanse towns. ${ }^{27}$ In fact, lay brothers manned ships and sailed several times a year to Bruges, Hamburg, Lübeck and even to Stralsund, to sell dairy products, hides and the like, and to buy grain, wood, building stone and other construction materials in return.

How far this specialization developed is difficult to say, but it is best to avoid emphasizing it too much without further explanation. The Frisian monasteries did their utmost to secure their own supply of rye, wheat, and other crops that did not grow in the coastal marsh lands. The Premonstratensian abbey of Wittewierum for instance, owned and used a grange, revealingly called Rogghenamunekan (Dutch rogge = rye) on the clay-on-peat soil of Garmerwolde, a few miles southwest of the monastery. ${ }^{28}$ Some Frisian abbeys, like Ludingakerke and Foswerd, who had no such soils in the surrounding region, provided for themselves by acquiring granges on sandy isles, like Texel and Ameland, while others (Haskerconvent, Staveren and Bloemkamp) even went as far as creating monk houses in

\footnotetext{
${ }^{25}$ There is a vast literature on the Cistercian economic system. A sharp analysis is presented by W. Rösener, 'Zur Wirtschaftstätigkeit der Zisterzienser im Hochmittelalter’, Zeitschrift für Agrargeschichte und Agrarsoziologie 30 (1982) pp. 117-148.

${ }^{26}$ On the Cistercian urban mansions, see: R. Schneider, 'Die Stadthöfe der Zisterzienser; zu ihrer Funktion und Bedeutung’, Zisterzienser Studien 4 (1979), pp. 11-28, and W. Schich, 'Die Wirschaftstätigkeit der Zisterzienser im Mittelalter: Handel und Gewerbe’, in: K. Elm ed., Die Zisterzienser. Ordensleben zwischen Ideal und Wirklichkeit (Cologne, 1981); pp. 217-236; 224-230; The town mansions of the Premonstratensians are treated in: B. van Bavel, 'schakels tussen abdij en stad. De stadshoven van de norbertijner abdijen in de Nederlanden (ca. 1250-ca. 1600), Analecta Praemonstratensia 76 (2000) pp. 133-157.

${ }^{27} \mathrm{Mol}$, 'Besitzerwerbungen der friesischen Zisterzienserklöster', pp. 88-89; idem, 'Bezitsverwerving en goederenbeheer van de abdij Aduard’, in: J. van Moolenbroek and J.A. Mol ed., De abtenkroniek van Aduard. Studies, edities en vertaling (Hilversum, 2010), pp. 173-202; 190-192.

${ }^{28}$ Groninger Archieven, Kloosterarchieven, inv.nr. 4 (1301).
} 
Salland (Staphorst and Zalk) and on the Veluwe (Oosterwolde) in Guelders. As for the other functions of agrarian production, the web of granges for each monastery reveals that every large abbey had several granges for arable farming on the high marsh ridges in the North, to secure the production of oats and barley, and some others in the lower marshes behind these ridges, for cattle breeding. ${ }^{29}$ Apart from that, a few large monasteries acquired granges in the moors and heaths in the southern parts of Frisia, where they kept sheep. Furthermore, nearly all monasteries were interested in the provision of fuel in the form of peat, but only the large ones - especially the Cistercian abbeys Klaarkamp, Aduard and Gerkesklooster - could afford to maintain peat digging centers of their own. These peat production centers were often in the same areas, or sometimes operated in combination with one or more tile works. Looking at the functions and distribution of the webs of granges per monastery, it can be stated that most monasteries indeed tried to realize a certain degree of self sufficiency.

\section{Structure and size: the Cistercian example?}

The Cistercians were not the first to introduce the grange system in Frisia. In fact, as we have seen, other monks arrived at an earlier stage in the region, and their monasteries appear to have already established granges in the Frisian coastal area before the arrival of the Cistercians around 1163. That is to say, the Benedictines who already were present in Staveren in 1132, are known to have operated a series of granges. The same goes for the Augustine canons, who settled in Ludingakerke in 1158. To be sure, none of our data on the granges of Staveren relates to units that functioned between 1132 and $1163,{ }^{30}$ but there is no reason to doubt that at least a few of them were founded within 25 years after the first Benedictine monks arrived in Staveren. This compels us to ask which model or format of the grange they had copied. Until recently, we did not know very much about the economic history of Staveren's mother house, the St-Laurens abbey of Oostbroek near Utrecht, that was founded as a double monastery or mixed community in 1122. But through an investigation of the donation and exploitation charters that have been preserved for Oostbroek however, Lotty Broer recently has demonstrated though that its monks had many conversi (lay brothers) in their midst, who were active in creating and operating granges, both on outlying properties in the Guelders river area and on lands near the abbey complex, east of the city of Utrecht. ${ }^{31} \mathrm{~A}$ recent survey on the - alas, scarcely documented - Oostbroek granges shows that the abbey of St-Laurens and the nunnery of Vrouwenklooster that was founded and developed under her guidance, owned more than twelve granges which were used as self-contained farms prior to their transformation into leasehold farms at the end of the thirteenth century. ${ }^{32}$

These Oostbroek granges do not seem to have been very large in size, at about 40 to 50 hectares on average. They are called curtes or uithoven in Latin and later Dutch sources. As for their structure, it is clear the Oostbroek monks modeled their granges on the large farm units of their mother abbey of Affligem in Brabant. ${ }^{33}$ Although no recent study has been made of the early economic history of this large Brabantine monastery, founded in 1083, it seems that up to ca. 1300 its Benedictine monks utilized a large part of their property as large curtis or grangia units, in the same manner as the Cistercians and Premonstratensians controlled and operated their own properties. The Benedictines of Affligem too placed each curtis of grange

\footnotetext{
${ }^{29}$ Mol, 'Mariëngaarde, het Friese kloosterwezen en de Friese maatschappij', pp. 90-96.

${ }^{30}$ The first notices on granges of the abbey of Staveren only date from 1245: Mol and Van Vliet, 'Oudste oorkonden van het Sint-Odulfusklooster', p. 124.

${ }^{31}$ Broer, Monniken in het moeras, pp. 123-132, 170-172; P.H. Damsté, 'De Uithof', Jaarboek Oud Utrecht 1968, pp. 143-162.

${ }^{32}$ R. Raven, chapters 2, 'Oostbroek als ontginningsgebied' and 3, 'De abdij Oostbroek als agrarisch bedrijf', in: F. Vogelzang and R. Raven (red.), Van Wildernis tot oase. Landschapsgeschiedenis van landgoed Oostbroek bij De Bilt (Utrecht 2013) pp. 39-40, 48-50, 67-70.

${ }^{33}$ Cf. note 8 .
} 
under the command of a laybrother as magister grangiae. ${ }^{34}$ More information on both the Oostbroek and Affligem granges or curtes is needed to determine whether the granges of the Oostbroek's daughter abbey of Staveren had the same structure, but it is very likely that they did. A similar parallel can be surmised for the early granges of Ludingakerke, which must have resembled the curtes ecclesie of its mother abbey of Kloosterrade in Limburg and the Eifel. ${ }^{35}$ A problem here one should be aware of, is that the Latin term curtis generally refers to a manor, in the sense of the center of a bipartite system, manned and staffed by serfs, consisting of a demesne and a series of dependent tenures. ${ }^{36}$ The curtes of Oostbroek and Kloosterrade were managed by lay brothers instead of serfs, whilst there were no demesnes anymore to be worked by unfree peasants. It is however possible that after ca. 1100 some 'new' monastic granges (or curtes for that matter) consisted of 'old' curtes or manors which, after being donated to a monastery, had been transformed by the monks by bringing in lay brothers to organize the exploitation. In these cases, one could speak of manors with a 'second life' as grange. ${ }^{37}$

Among the granges of Staveren and Ludingakerke - as well as granges of other monasteries that were involved in pastoral work - we find a certain type, which the Cistercians did not acquire or create. This is the monk house near, or in combination with a rectory. The town of Monnikendam in Holland owes its name to such a grange, set up by the Augustine canons of Ludingakerke. ${ }^{38}$ Another instructive example is offered by the Munickhuus of the Benedictines of Foswerd near the St-Martins church of Ferwerd (fig. $\mathrm{xxx}) .{ }^{39}$ Originally this church was owned by the bishop of Utrecht. He appears to have donated it to the new monastery under the condition that it should be administered by one of its priest brethren. ${ }^{40}$ Research into the size and location of the monk house's building and main parcel, which stood close to the church building itself and was on the lands of the church (ecclesiae fabrica), demonstrates that the Benedictines of Foswerd must have separated the parcel from the original glebe complex, to exploit it as their own while they left the rest of the parish church lands intact for maintenance on the church building (to be administered by church wardens). This type of grange is more frequent in Friesland west of the Lauwers than in Groningen, because the Utrecht bishop promoted the transfer of parish churches to monasteries more often than his colleagues of Münster and Osnabrück, who ecclesiastically reigned over the Frisian territories in the province of Groningen and the regions further to the east. ${ }^{41}$ Such monk houses in the center of the village had generally less land attached to them

\footnotetext{
${ }^{34}$ About 1280, Affligem still exploited no less than 20 of these units 'en faire valoir-direct': A. Despy-Meyer and C. Gerard, 'L’abbaye d’Affligem, à Hekelgem', in: U. Berlière e.a. (ed.), Monasticon Belge IV. Province de Brabant (Liège 1964-1972) pp. 35-41.

35 The estates of Kloosterrade were utilized in 7 curtes by the canons themselves, probably with the help of lay brothers: L. Augustus and J.T.J. Jamar (ed.), Annales Rodenses. Kroniek van Kloosterrade. Tekst en Vertaling ((Maastricht 1995), pp. 38-39; compare P.C. Boeren, 'Het grondbezit der abdij Rolduc in de jaren 1104-1300', Publications de la Société historique et archéologique dans le Limbourg 84 (1948) pp. 141-196.

${ }^{36}$ Van Bavel, Manors and Markets, pp. 75-82.

${ }^{37}$ In Friesland, this type was not very common since the manorial system had not been widely adopted here. One clear cut example concerns the Monnikenhove of the Augustine abbey of Ludingakerk near the village centre of Den Burg on the isle of Texel (fig. xxx), of which we know that it had been a manor of the count of Holland. Originally it had made part of a large property complex which included the ecclesia matrix of the isle, dedicated to St-Sixtus. The manor - under the name of Gravendael - was at some time in the middle of the thirteenth century transferred to Ludingakerke by the count: $\mathrm{H}$. Schoorl, 'De uithoven van Ludingakerke op Texel', De Vrije Fries 76 (1996) pp. 87-108.

${ }^{38}$ J.A. Mol, 'Graaf Willem IV, de Hollands-Friese oorlog van 1344/1345 en de Friese kloosters', in: Ph.H. Breuker \& A. Janse ed., Negen eeuwen Friesland-Holland. Geschiedenis van een haat-liefdeverhouding (Zutphen, 1997) pp. 94-108; 97-98.

39 The Ferwerd 'Munickhuus' is recorded in the so-called Register van den Aanbreng van 1511, ed. by I. Telting (Leeuwarden, 1879/1880), a land tax register made up on behalf of the Duke of Saxony: I, p. 93; III, p. 63. ${ }^{40}$ Oorkondenboek van het Sticht Utrecht IV, F. Ketner ed. (The Hague 1954) nrs. 2388 (1289) and 2423 (after 1290).

${ }^{41}$ O.D.J. Roemeling, Heiligen en Heren. Studies over het parochiewezen in het Noorden van Nederland vóór 1600 (Leeuwarden 2013), pp. 129-131.
} 
than the 'classic' outlying agricultural units we are most familiar with. One reason is that such divided glebe units were not large by themselves. They were also usually located in settlements and areas which had long been occupied and in which but few new lands could be acquired.

One would expect the Premonstratensian abbeys to have created many granges of this 'near-the-parish-church' type, because they had the best reputation as religious communities with pastoral tasks. But this was not the case. The large twelfth century abbeys of Mariëngaarde and Lidlum had only two of these. ${ }^{42}$ The rest of their granges had a more Cistercian outlook. That is to say, their monk houses had on average a size of more than 200 acres (or $80 \mathrm{ha}$ ), and not the alternative size. From these granges, lay brothers operated a large-scale enterprise. This becomes very clear in the figures on the cattle of the two granges of Mariëngaarde at the isle of Marken, documented at the moment when they were confiscated by the count of Holland in his war with Frisia west of the Lauwers, in $1345 .{ }^{43}$ The Westhuse, probably located near the present village of Marken, covered an area of 174 acres (or 64 ha), the Oesthuse girded 330 acres (or 126 ha). The former had a livestock of 55 cows and 17 horses, the latter counted 33 cows and 7 horses, which exceeds by far the number of animals that was held at the common farm of a single family. The two granges combined encompassed about half of the isle, which was then probably much larger than it is at present, owing to the effects of soil erosion. (ca. 1170 acres or $430 \mathrm{ha}$ ). The other half of the island was also owned by the abbey and leased out to tenants.

\footnotetext{
${ }^{42}$ In casu Spannum and Winsum (Lidlum), and Stiens and Oosternijkerk (Mariëngaarde): see the documentation in the layer 'uithoven' in www.hisgis.nl/Fryslân.

${ }^{43}$ R.C. Bakhuizen van den Brink, 'Markerhoofd', De Vrije Fries 10 (1865) pp. 101-143; 122 ff.
} 


\begin{tabular}{|lrrr|}
\hline & Westhuse & Oesthuse & Total \\
Horses & 17 & 4 & 24 \\
Foals & 3 & 1 & 4 \\
Cows & 55 & 33 & 88 \\
Heifers & 4 & 5 & 9 \\
Bulls & 1 & 2 & 3 \\
Oxen & 2 & & 2 \\
Calfs & 6 & 10 & 16 \\
Pigs & 5 & 13 & 18 \\
Total & 93 & 68 & 164 \\
\hline
\end{tabular}

In this fashion the Frisian Premonstratensian granges did not resemble the early curiae that were exploited by the abbeys of Prémontré and Knechtsteden in the twelfth century, of which there were many but who each were relatively small in size. According to the German historian Dietrich Lohrmann, these abbeys owned no less than 26 and 33 curiae in 1135 and 1160 respectively. This led Lohrmann to the conclusion that the Premonstratensian grange in its early and rudiment form was much smaller in structure than the Cistercian one. ${ }^{44}$ The Cistercians thus are thought to have had fewer but larger units.

However, when we compare the granges of the Frisian Benedictines, Augustine canons and Premonstratensians with those of the Cistercians based on their size, it is difficult to find any differences. Of course, we cannot establish the size of every grange, but when we look at the specific granges listed in monastic property surveys of 1600, we discover that they were of similar size. In the province of Friesland, for instance, the large monk house of the Klaarkamp Cistercians at the village of Holwerd, which apparently had been leased out in 5 units in the fifteenth century, had - when taken these units together - an overall size of 510 acres or 187 ha of very fertile clay land. In addition, the reconstructions that were made of the landed property of the Bloemhof/Wittewierum (Prem.) and Feldwerd (Ben.) granges in the Groningen Fivel estuary, ${ }^{45}$ which date from the first half of the thirteenth century, give the impression that all orders at that time tried to create exploitation units that were at least as large as the Cistercian ones.

It is difficult to determine whether these thirteenth century granges marked the end of an evolution towards the ideal 'Frisian' size or if they had been established with the more or less ideal measures copied from the original Cistercian size. I am inclined to believe that each of the orders started with its own model, derived from their mother houses in the South - the Oostbroek model for instance, and certainly also the 'monkhouse-near-the-church' variant but that each order soon discovered that the Cistercians had the best template for agrarian production to offer in Frisia. An indication - although a slightly circumstantial one - for this hypothesis is that in the well known thirteenth century chronicles which have been preserved for the Premonstratensians of Mariëngaarde in the province of Friesland and Wittewierum in the province of Groningen, the granges are not designated with the Premonstratensian term curia, but are consistently labelled with the Cistercian term grangia. ${ }^{46}$ The same goes for the contemporary sources of the Augustine canons, the Hospitallers and the Teutonic Order, who

\footnotetext{
${ }^{44}$ D. Lohrmann, 'Répartition et création de nouveaux domaines monastiques au XIIe siècle: Beauvasis Soissonnais - Vermandois’, in: W. Janssen and D. Lohrmann ed., Villa -Curtis -Grangia. Landwirtschaft zwischen Loire und Rhein von der Römerzeit zum Hochmittelalter (München/Zürich, 1982) pp. 242-259, 243; idem, 'Die Wirtschaftshöfe der Prämonstratenser im hohen und späten Mittelalter’', in: H. Patze ed., Die Grundherrschaft im Mittelalter I (Sigmaringen 1983), pp. 205-241.

${ }^{45}$ www.hisgis.nl s.v. Groningen, layer 'kloostergoederen'.

${ }^{46}$ H.P.H. Jansen and A. Janse ed., Kroniek van het klooster Bloemhof te Wittewierum (Hilversum, 1991); Lambooij and Mol, Vitae Abbatum Orti Sancte Marie, s.v. uithoven.
} 
in other regions seldom used the term grangia ${ }^{47}$ Furthermore, it might be possible that the orders, known to have strongly competed for the favors of the public, learned what the best qualities of their rivals were from this competition. As a consequence, they soon came to copy the apparently superior Cistercian model in the economic field.

To test this assumption, we need more data on the structure of the building complexes of the granges. Unfortunately, hardly any of the abovementioned 173 granges has been researched by archaeologists even in our current time. There is only one, named the Hoogeheem, which has been excavated recently (2005-2007). ${ }^{48}$ This grange was located just outside Frisian territory and did not even belong to a Frisian monastery. However, it was a grange of a Cistercian house, the nunnery of Marienkamp, which was founded near Coevorden in Southeast Drenthe between 1234 and 1246 but had been forced to move to Assen in the North of the province around 1253/1254. ${ }^{49}$ Its precincts encompassed 5 acres of land lying in a large rectangular block. The site, including a part of its buildings, were excavated by archaeologists about five or six years ago, because of the construction of a new industrial zone at the west side of the town. The recently published report of the results makes clear that the grange was built from scratch around 1290/1300. The lay brothers who are supposed to have constructed it, first made a platform of clay, measuring $50 \times 40$ meters, which they subsequently extended by digging a moat around both the platform and an adjacent plot through which a separated space was formed of $200 \times 100$ meters.

At first sight it is puzzling that such a structure was made for a nunnery, since monasteries for women are not known for intensive exploitation of their property. The answer comes when we realize that the moving or migration of the Cistercian nuns was carried out under the guidance of their father abbot, of Aduard. It appears as if the grange has been built by brothers of Aduard, be it a property of Aduard to be sold or transferred to the nuns, or perhaps a property developed by the nuns after they had acquired the abandoned property in some other way. The first possibility seems the most probable though, because the location of the lands belonging to the Hoogeheem nearly dovetails with the large core complex of Aduard lying on the more fertile clay lands to the north. ${ }^{50}$ This means Aduard likely had this extra land available for development.

There are many grange sites in Frisia which at first sight show a similar systematic rectangular ground plan. These include the monk houses of Holwerd and Nes, belonging to the Cistercian abbey of Klaarkamp, the Holwerd Wit Monnikhuis of the Premonstratensian abbey of Dokkum, the Westeremder Voorwerk and the Zandster Voorwerk of the Premonstratensensian abbey of Wittewierum, and the Kolholster Voorwerk of the Benedictine abbey of Feldwerd. The first three were located along the North Frisian Wadden sea coast, the latter three had been built in the silted-up Fivel estuary in Groningen. But none of these have been studied by archaeologists thus far. The same goes for the remains of a much earlier grange - dating from the twelfth century - of the Flemish Cistercian abbey of Ter Doest near Bruges, at the island of Zuid-Beveland in the province of Zeeland. The grange there was called Monnikhof or Monsterhoek. ${ }^{51}$ By zooming in on the village of Kattendijke on the Dutch Digital Altitude Map, it appears that the grange of the Ter Doest abby had roughly the same

\footnotetext{
47 J.A. Mol, 'Die Wirtschaftsführung der Ritterorden in den friesischen Ländern', in: R. Czaja en J. Sarnowsky, ed., Die Ritterorden in der europäischen Wirtschaft des Mittelalters, Ordines Militares - Colloquia Torunensia Historica 11 (Torun 2003) pp. 107-128, here 114-117.

${ }^{48}$ The excavation has recently been described and analysed in an extensive report: J.Y. Huys in't Veld, J.Y., Het Hoogeheem, een Drents kloostervoorwerk in Groningen. Een opgraving van een podium uit de late middeleeuwen bij Hoogkerk, Stadse Fratsen 28 (Groningen, 2011).

${ }^{49}$ M.M. de Bakker, 'De abdij Marienkamp te Assen', Nieuwe Drentse Volksalmanak 77 (1959) pp. 14-63, 19; F. Bakker, 'De stichting en vroegste geschiedenis van de Drentse abdij', Nieuwe Drentse Volksalmanak 2001, pp. $1-12$.

${ }^{50}$ www.hisgis.nl: Groningen and Drenthe.

${ }^{51}$ C. Dekker, Zuid-Beveland. De historische geografie en de instellingen van een Zeeuws eiland in de middeleeuwen (Assen, 1971), pp. 99-105.
} 
spatial disposition as the Hoogeheem and the other abovementioned sites. ${ }^{52}$ The only site of a Ter Doest grange which has been excavated, is the uithof Oosthoek near Hellevoetsluis at the Holland island of Voorne. Research here, however, has unfortunately produced no clear picture of the ground plan and main features of the grange. ${ }^{53}$

For now, much more interdisciplinary research is needed with regard to the outlook and construction of the granges in the monastic landscape of the Low Countries. The archaeological findings at the Hoogeheem site show that lay brothers in the late thirteenth century worked systematically and thoroughly to develop a grange from scratch on a flat clayon-peat soil at the border of Groningen and Drenthe.

\section{Conclusion}

When we look at the Frisian landscape as it was used and experienced in the medieval period, it can be stated that it bore a clear monastic stamp, not only through the many religious houses on the land but also through their numerous outlying farms and other agricultural units manned by lay brothers. Our preliminary study of the Frisian granges, or 'monk houses', has shown that neither the grange system nor the massive deployment of conversi was a Cistercian specialty. In fact, ultimately all orders disposed of granges, and all of them came to employ lay brothers as well. As for the introduction of the system in Frisia, it looks as if the Benedictines of the Affligem-Oostbroek-Staveren filiation were responsible. They, together with other orders who were active in pastoral care, initially developed small or medium sized monk houses, some of which were attached to parish churches under their patronage. The Cistercians were not interested in this type. Where they could build them from scratch on the flat clay soil they created comparatively large agricultural units, with building complexes on heightened platforms surrounded by moats. Some monasteries of other orders did build up such large granges as well. It is not yet clear whether they copied the Cistercian model in doing so. The fact that their units were designated mostly as grangiae in Latin - the Cistercian term - suggests however that this might have been the case. Further research may reveal whether this Frisian development has general traits. This cannot be ruled out, since it was established that in Frisian coastal area all orders not only had the same starting point but also met the same conditions, in the sense that they had to compete with one another without the power and preference of kings, bishops and other mighty men playing a decisive role. More research is needed on this theme, both to discover the size and composition of the granges, and to better understand the nature of the lay brother communities.

\footnotetext{
${ }^{52}$ www.ahn.nl.

53 A. Carmiggelt e.a. (ed.), Een $13^{e}$-eeuwse begraafplaats te Hellevoetsluis bij de uithof Oosthoek van de Vlaamse cisterciënzerabdij Ter Doest. Archeologisch, historisch en fysisch-antropologisch onderzoek, BOORrapporten 17 (Rotterdam 1999). In fact, the archaeologists seem to have found here not the grange itself but only the groundwork of an early thirteenth century parish settlement, with a church, a graveyard and a small motte-and-bailey castle, in the neighborhood of which - but unclear as to where exactly - the grange must have been constructed.
} 
Annex: the monasteries in the provinces of Friesland and Groningen and their granges

\begin{tabular}{|c|c|c|c|c|c|c|c|c|}
\hline 1. Fryslân & status & order & start & in $F$. & ex $F$ & tot. & city & size \\
\hline Staveren/Hemelum & abbey & Ben. & 1132 & 8 & 3 & 11 & 1 & 1217 \\
\hline Hemelum & propstei & Ben. w. & $>1245$ & 2 & 3 & 5 & & \\
\hline Foswerd & abbey & Ben. & $>1200$ & 6 & & 6 & & 1049 \\
\hline Smalle Ee & abbey & Ben. & $\begin{array}{r}\text { ca } \\
1200\end{array}$ & 2 & & 2 & & 1169 \\
\hline Ludingakerke (+ Achlum) & abbey & Aug. & 1158 & 6 & 3 & 9 & 1 & 947 \\
\hline Bergum & propstei & Aug. & $\begin{array}{r}\mathrm{ca} \\
1200\end{array}$ & 5 & & 5 & 1 & 1287 \\
\hline Haskerconvent & propstei & Aug. & 1231 & 1 & 1 & 2 & & 882 \\
\hline Anjum & propstei & Aug. & 1256 & 2 & 1 & 3 & & 709 \\
\hline Klaarkamp + Sion, Nazareth & abbey & Cist. & 1163 & 10 & 1 & 11 & 1 & 4100 \\
\hline Bloemkamp + Nijeklooster & abbey & Cist. & 1191 & 7 & 1 & 8 & 1 & 1871 \\
\hline Gerkesklooster + Vrouwenkl. & abbey & Cist. & 1240 & 6 & & 6 & 1 & 2773 \\
\hline Mariëngaarde + Betlehem & abbey & Prem. & 1163 & 7 & 2 & 9 & 1 & 2176 \\
\hline Lidlum + Bajum, Miedum, Franjum & abbey & Prem. & 1182 & 12 & & 12 & & 1883 \\
\hline Dokkum + Weerd & abbey & Prem. & $>1175$ & 4 & & 4 & & 1500 \\
\hline t Zand alias Vinea Domini & propstei & Prem. & ? 1266 & 2 & & 2 & & 456 \\
\hline Buweklooster & propstei & Prem. & $\begin{array}{r}\text { ca } \\
1250\end{array}$ & 1 & & 1 & & 330 \\
\hline Veenklooster & propstei & Prem. & $>1287$ & 1 & & 1 & & 229 \\
\hline Hospitaal Sneek & comm. & Hosp. & $>1240$ & 4 & & 4 & & 673 \\
\hline Nes + Katrijp Steenkerk & comm. & Teut. & $>1243$ & 2 & & 2 & & 779 \\
\hline Schoten & comm. & Teut. & $>1298$ & & & & & 121 \\
\hline Sub total Fr. & & & & 88 & 15 & 103 & 7 & 24151 \\
\hline 2. Groningen & status & order & start & in $\mathrm{F}$. & ex $F$ & tot. & city & size \\
\hline Selwerd & abbey & Ben. & $\begin{array}{r}\mathrm{ca} \\
1207\end{array}$ & 2 & & 2 & 1 & 1599 \\
\hline Feldwerd & abbey & Ben. & $\begin{array}{r}\text { ca } \\
1180\end{array}$ & 7 & & 7 & & 1300 \\
\hline Rottum & abbey & Ben. & $>1226$ & 4 & & 4 & & 1183 \\
\hline Thesinge/Ten Boer & abbey & Ben. & $>1301$ & 1 & & 1 & & 1233 \\
\hline Aduard + Sint Annen & abbey & Cist. & 1192 & 10 & 2 & 12 & 1 & 6732 \\
\hline Menterna + Midwolda & abbey & Cist. & $>1247$ & 4 & 1 & 5 & & 1902 \\
\hline Essen (autonomous Cist. nunnery) & abbey & Cist. w. & 1215 & 2 & & 2 & & 3000 \\
\hline Oldeklooster Marne + Nijekl. & abbey & Prem. & $>1175$ & 2 & & 2 & 1 & 980 \\
\hline Bloemhof Wittwierum + Nijekl. & abbey & Prem. & 1204 & 10 & & 10 & 1 & 2657 \\
\hline Schildwolde & propstei & Prem. & $>1204$ & 3 & & 3 & & 483 \\
\hline Heiligerlee & propstei & Prem. & $>1230$ & 3 & & 3 & & 1473 \\
\hline Kuzemer & propstei & Prem. & $>1287$ & & & & & 710 \\
\hline Palmar & propstei & Prem. & $14 \mathrm{e} e$. & & 1 & 1 & & \\
\hline Warffum & comm. & Hosp. & $\begin{array}{r}\mathrm{ca} \\
1240\end{array}$ & 6 & & 6 & 1 & 1743 \\
\hline Wijtwerd & comm. & Hosp. & $\begin{array}{r}\mathrm{ca} \\
1240\end{array}$ & 4 & & 4 & & 906 \\
\hline Oosterwierum & comm. & Hosp. & $>1319$ & 6 & & 6 & & 1521 \\
\hline Goldhoorn & comm. & Hosp. & $14 \mathrm{e} e$. & & 1 & 1 & & \\
\hline Oosterwijtwerd & comm. & Hosp. & $14 \mathrm{e}$ e. & & 1 & 1 & & \\
\hline Sub total Gr. & & & & 64 & 6 & 70 & & 27422 \\
\hline \multicolumn{4}{|l|}{ Summa summarum } & 152 & 21 & 173 & 7 & 51573 \\
\hline
\end{tabular}

